\title{
Pengaruh Social Media Marketing, Fasilitas Wisata Dan Citra Destinasi Wisata Terhadap Minat Wisatawan Berkunjung
}

\author{
Chintya Ones Charli, Della Asmaria Putri \\ Universitas Putra Indonesia YPTK Padang, Indonesia \\ Email: chintyaonescharli@upiyptk.ac.id
}

\begin{abstract}
Abstrak
Melihat besarnya potensi dari industri pariwisata di Sumatera Barat, masih banyak variabel penelitian yang perlu diteliti terkait dengan minat wisatawan untuk terus berkunjung ke sejumlah objek wisata yang ada di Sumatera Barat. Dilatar belakangi oleh hal tersebut, peneliti melakukan penelitian yang bertujuan untuk menganalis pengaruh Social Media Marketing, Fasilitas Wisata dan Citra Destinasi Wisata terhadap Minat Wisatawan Berkunjung. Populasi pada penelitian ini adalah wisatawan yang pernah mengunjungi objek wisata di Pulau Mandeh Kabupaten Pesisir Selatan, Sumatera Barat. Pada penelitian ini Sampel diambil dengan teknik accidental sampling method dengan menyebarkan angket penelitian sebanyak 239 orang responden. Penelitian ini menggunakan analisis regresi melalui software SPSS untuk menganalisis data, dengan melakukan pengujian validitas, reabilitas, uji asumsi klasik dan pengujian hipotesis berupa Uji-t dan Uji-F. Hasil yang didapatkan dalam penelitian ini yaitu terdapat pengaruh yang signifikan Social Media Marketing, Fasilitas Wisata dan Citra Destinasi Wisata terhadap Minat Wisatawan Berkunjung pada objek wisata Pulau Mandeh baik secara persial maupun secara simultan. Hal ini menunjukan bahwa sosial media, fasilitas wisata dan Citra Destinasi Wisata yang ada pada kawasan pulau mandeh sudah mampu menarik minat wisatawan untuk berkunjung kembali dan tetap meningkatkan promosi melalui sosial media, meningkatkan fasilitas wisata dan menambah Citra Destinasi Wisata yang baru sehingga wisatawan tidak merasa bosan untuk berkunjung.
\end{abstract}

Kata Kunci: Sosial Media, Fasiltas, Destinasi, Minat

\section{Pendahuluan}

Provinsi Sumatera Barat merupakan salah satu provinsi yang memiliki berbagai macam potensi wisata, potensi wisata tersebut adalah wisata alam dan wisata kebudayaan. Kayanya Sumatera Barat akan potensi alamnya juga dapat digali dan diberdayakan untuk dikembangkan dan dimanfaatkan sebagai objek pariwisata. Selain itu sumatera barat memiliki beragam seni budaya daerahnya, mulai dari adat istiadat dan peninggalan sejarah terdahulu serta yang tidak kalah menarik adalah keindahan panorama alamnya yang cukup potensial untuk dikembangkan dengan baik. Kehidupan masyarakat masih kental dengan kebudayaan, karena sumatera barat merupakan daerah yang memiliki keberagaman budaya, dan juga terkenal dengan panorama alamnya dan pariwisata.

Ternyata sektor pariwisata juga dapat diandalkan dalam meningkatkan kesejahteraan masyarakat dan pembangunan daerah. Pariwisata dapat menunjang kemajuan suatu daerah, maka tak heran seluruh daerah yang ada di sumatera barat mulai berlomba-lomba membenahi sektor pariwisata daerah untuk menjadikan daerahnya menjadi salah satu Citra Destinasi Wisata yang baik dan aman bagi wisatawan yang akan berkunjung. Pariwisata mempunyai daya tarik sendiri dalam meningkatkan branding suatu daerah atau kota. Di Sumatera Barat tingkat wisatawan yang berkunjung sangatlah tinggi setiap tahunnya, apalagi wisatawan yang berasal dari timur tengah, hal inilah yang memacu setiap daerah untuk membenahi wisata daerahnya. Tak hanya itu saja, pariwisata juga merupakan sesuatu hal yang sangat penting dalam peningkatan pendapatan daerah dan memacu pertumbuhan perekonomian daerah.

Minat merupakan kekuatan pendorong kesadaran seseorang terhadap suatu objek yang menyebabkan seseorang menaruh perhatian pada sesuatu yang dia sukai yang berdampak pada peningkatan pasar. Minat berkunjung ulang muncul akibat dari adanya proses belajar dan proses pemikiran yang kemudian membentuk suatu persepsi. Minat berkunjung ini akan muncul dan kemudian menjadi Fasilitas Wisata yang terus terekam dalam fikirannya dan menjadi kegiatan yang sangat kuat yang pada akhirnya ketika seseorang merasa ingin merasakan hal yang sama maka akan 
mengaktualisasikan apa yang menjadi Fasilitas Wisata dalam fikiranya. Minat merupakan suatu kesadaran seseorang terhadap suatu objek, seseorang, suatu soal atau juga situasi tertentu yang mengadung sangkut paut dengan dirinya atau dipandang ialah sebagai sesuatu yang sadar (Witherington, 2015).

Alasan - alasan yang digunakan untuk melakukan perjalanan wisata pun beragam, mulai dari menghilangkan penat dari pekerjaan sehari-hari, hingga melakukan perjalanan wisata untuk berkumpul bersama keluarga. Banyak faktor yang Fasilitas Wisata wisatawan dalam mengambil keputusan berkunjung antara lain Media Sosial Marketing, Fasilitas dan Citra Destinasi. Oleh sebab itu, sosial media memang memiliki peranan penting dalam menjalankan strategi digital marketing karena dapat meningkatkan brand awareness. Sosial media pun memegang arti yang sangat penting dan menjadi bagian gaya hidup sebagian besar masyarakat di seluruh dunia. Masyarakat dunia sudah bisa menggunakan sosial media dan dipastikan jumlahnya akan semakin bertambah seiring berkembangnya teknologi. Selain itu fasilits wisata dan citra destinasi dimana Salah satu alasan yang mendorong wisatawan untuk berkunjung kembali ke sebuah objek wisata adalah keinginan wisatawan untuk mendapatkan hal baru. Seseorang yang memiliki ketertarikan terhadap sesuatu akan cenderung melakukan usaha untuk mendapatkannya lagi. Demikian juga bila seseorang memiliki kecenderungan untuk mencari hal-hal baru, maka mereka akan melakukan berbagai cara untuk mendapatkannya. Dengan demikian meningkatkan fasilitas wisata dengan berbagai inovasi inovasi baru akan dapat menunjang minat berkunjung wisatawan. Disamping itu, alasan seseorang ingin berkunjung kembali ke objek wisata adalah bagaimana Citra Destinasi Wisata yang akan mereka kunjungi, Citra destinasi juga bukanlah sesuatau yang statis namun sangat dinamis seiring dengan terjadinya perubahan ruang, waktu dan tempat.

Kabupaten Pesisir Selatan terletak di bagian selatan Provinsi Sumatera Barat dengan ibukotanya Painan yang berjarak $\pm 75 \mathrm{~km} 2$ dari Kota Padang. Kabupaten Pesisir Selatan memiliki cukup banyak Citra Destinasi Wisata yang sudah menjadi tujuan wisata di Propinsi Sumatera Barat salah satunya adalah Pantai Carocok Painan dengan Pulai Cingkuak di Kecamatan IV Jurai dan Kawasan Wisata Mandeh di Kecamatan Koto XI Tarusan, disamping itu masih terdapat objek wisata lainnya yaitu Bukit Langkisau, Air Terjun Banyang Sani, Air Terjun Timbulun, Jembatan Akar dan Batu Kalang Tarusan. Disamping itu Kabupaten Pesisir Selatan juga memiliki objek wisata sejarah yaitu Rumah Gadang Mandeh Rubiah, Masjid Tua, Benteng Portugis dan kesenian tradisional yaitu Rabab Pasisie.

Kawasan Mandeh merupakan salah satu Destinasi Utama Pariwisata Kabupaten (DUPK) sesuai dengan Peraturan Daerah Nomor 2 Tahun 2015 tentang Rencana Induk Pembangunan Kepariwisataan Kabupaten Pesisir Selatan. Berikut tabel kunjungan Wisatawan mancanegara ke indonesia beberapa tahun terakhir adalah sebagai berikut :

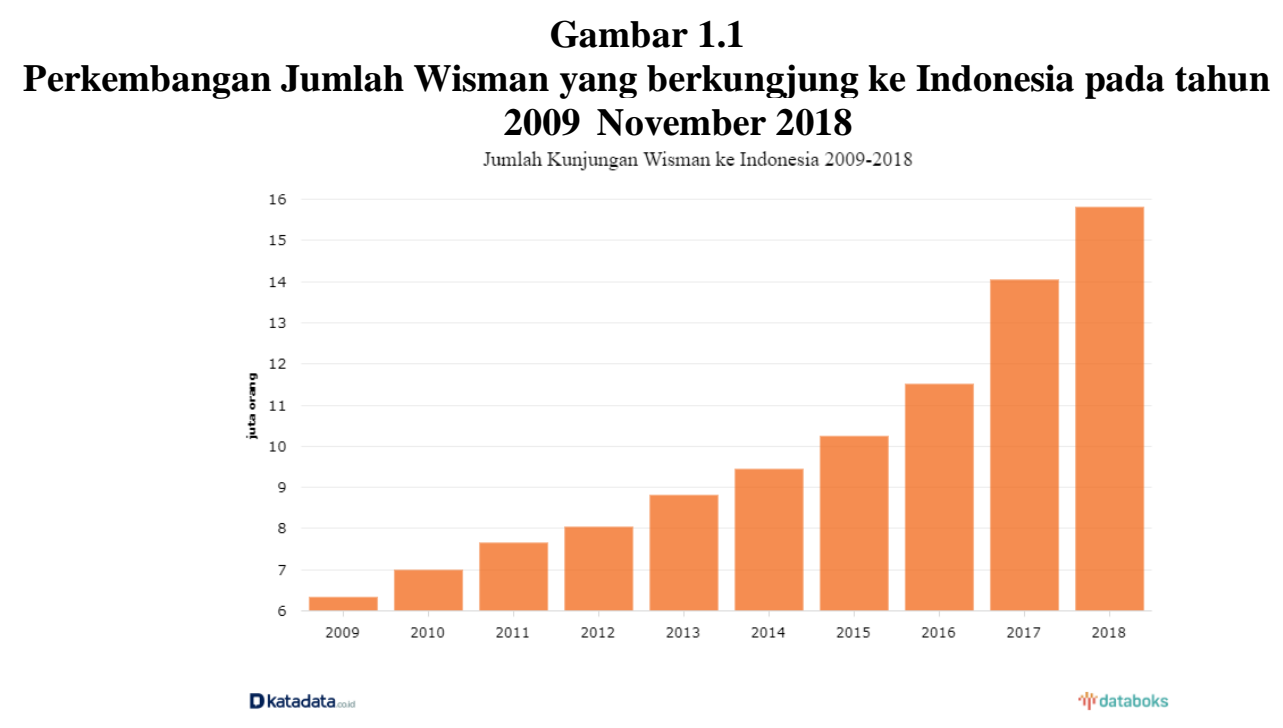

Sumber : Badan Pusat Statistik (BPS), 2019 
Rata-rata pertumbuhan kunjungan wisatawan mancanegara (wisman) ke Indonesia dalam lima tahun terakhir (2014-2018) mencapai 14\% per tahun. Angka ini lebih tinggi dibandingkan rata-rata pertumbuhan kunjungan wisman pada periode 2009-2013 yang sebesar 9\% per tahun.Menurut data Badan Pusat Statistik (BPS), kunjungan wisman pada 2009 tercatat sebanyak 6,32 juta orang. Angka ini terus meningkat menjadi 8,8 juta orang pada akhir 2013.Pada 2018, jumlah kunjungan wisman ke Indonesia mencapai 15,81 juta orang atau tumbuh sekitar 2,5 kali lipat dibandingkan 2009. Tahun ini pemerintah menargetkan kunjungan wisman bisa mencapai 18 juta orang.(Baca Databoks: Realisasi Investasi Sektor Pariwisata Capai Rp 20,9 Triliun pada 2018).

Namun, berdasarkan data Badan Pusat Statistik, kunjungan wisatawan mancanegara ke Sumatera Barat belum terlihat peningkatan yang signifikan. Berikut tabel yang menunjukkan data jumlah wisatawan mancanegara ke Sumatera Barat :

Tabel 1. Data Jumlah Wisatawan Mancanegara Sumatera Barat

\begin{tabular}{ccc}
\hline No & Tahun & Jumlah Wisman \\
\hline 1 & 2015 & 49.784 \\
2 & 2016 & 49.686 \\
3 & 2017 & 56.313 \\
4 & 2018 & 54.356 \\
\hline
\end{tabular}

Sumber : Badan Pusat Statistik (BPS), 2019

Penurunan jumlah wisatawan pada tahun 2018 menunjukkan bahwa masih terdapat faktor yang menghambat minat wisatawan untuk datang kembali ke Sumatera Barat. Minat untuk berkunjung kembali terkait dengan keputusan wisatawan untuk melakukan kunjungan berulang. Sosial media adalah informasi paling baik bagi konsumen untuk mendapatkan berbagai informasi teks, gambar, video, dan audio dengan satu sama lain. sosial media diyakini memiliki fungsi yang sangat penting dalam menjalankan strategi digital marketing karena dapat meningkatkan brand awareness. Sosial media pun memiliki arti yang sangat penting dalam gaya hidup sebagian besar masyarakat di indonesia. Penduduk indonesia sudah bisa menggunakan sosial media dan dipastikan jumlahnya akan semakin bertambah seiring berkembangnya teknologi.

Kawasan Mandeh merupakan teluk yang dikelilingi pulau-pulau eksotis, beberapa pulau yang ada di lokasi ialah Pulau Cubadak dan Pulau Mandeh, pulau ini memiliki kekayaan bawah laut yang melimpah sehingga aneka jenis terumbu karang dan biota laut sangat mudah ditemukan. Selain itu arus lautnya juga tenang sehingga lokasi ini menjadi favorit para penyelam lokal dan dunia. Selanjutnya juga ada Pulau Sironjong Ketek, selain juga memiliki kekayaan biota laut, di pulau ini wisatawan juga bisa mengadu adrenalin dengan melompat dari ketinggian lebih kurang 20 meter ke perairan. Di lokasi terdapat tangga baja yang bisa digunakan wisatawan sebagai tempat melompat dan cukup aman dinaiki hingga puluhan orang.

Namun fasilitas wisata sangat dibutuhkan dalam mengelola kawasan pulau mandeh agar minat berkunjung wisatawan semakin meningkat, karena tanpa fasilitas yang memadai dunia pariwisata akan hambar, bahkan yang lebih fatal lagi sebuah destinasi tidak akan lagi dikunjungi wisatawan tanpa adanya fasilitas wisata yang memadai. Citra Citra Destinasi Wisatapun juga harus dijaga, sebab menjaga kepercayaan wisatawan, menjaga kenyamanan, keamanan dan kepuasan dari pengunjung akan dapat meningkatkan rasa loyal dari pengunjung sehingga wisatawan akan sendirinya mempromosikan lokasi wisata kepada rekan, teman, dan kerabatnya. Sehingga berdampak pada minat untuk berkunjung kembali dari wisatawan.

Penelitian yang dilakukan oleh Mavragani (2019) dengan judul Traveler segmentation through Social Media for intercultural marketing purposes: The case of Halkidiki. Dengan hasil penelitiannya dengan mensurvey pengguna di Instagram, Facebook, Twitter dan beberapa sosial media lainnya. Ditemukan adanya pengaruh yang besar sosial media marketing terhadap minat berkunjung.

Berdasarkan latar belakang masalah maka penulis tertarik untuk melakukan penelitian dengan judul "Pengaruh Social Media Marketing, Fasilitas Wisata dan Citra Destinasi Wisata terhadap Minat Wisatawan Berkunjung (Studi Kasus Pada Kawasan Mandeh, Kab. Pesisir Selatan)”. 


\section{Tinjauan Literatur}

\section{Defenisi Variabel \\ Social Media Marketing}

Menurut Rangkuti (2013) Sosial media adalah gabungan antara media teknologi informasi melalui internet, dengan kegiatan hubungan antar individu sehingga menjadikan nilai baru yang mampu meningkatkan hubungan antara kelompok maupun individu secara sosial. Media berbasis internet ini mendorong dan memungkinkan penggunanya saling terhubung dengan siapa saja, baik orang - orang terdekat hingga orang - orang asing yang tidak pernah dikenal sebelumnya.

\section{Fasilitas Wisata}

Fasilitas wisata merupakan suatu sarana dan prasarana yang disediakan oleh pengelola wisata untuk dapat digunakan oleh wisatawan. Wisatawan tidak hanya dapat menikmati keindahan alam atau keunikan objek wisata, melainkan memerlukan sarana dan prasarana wisata seperti akomodasi, kendaraan dan lain-lain. Menurut Jansen-Verbeke (1986) mengenai fasilitas wisata adalah fasilitas berupa bangunan yang timbul karena adanya daya tarik utama yang merupakan fasilitas primer. Fasilitas yang timbul karena adanya daya tarik antara lain fasilitas pengunjung. Fasilitas pengunjung adalah bangunan diluar fasilitas primer yang digunakan untuk memenuhi kebutuhan wisatawan selama masih berada dilokasi wisata.

\section{Citra Destinasi Wisata}

Citra destinasi didefinisiskan tidak hanya sebagai perlengkapan atau fasilitas destinasi tetapi juga kesan menyeluruh yang ditampilkan oleh destinasi. Multi dimensinya citra destinasi juga disebabkan oleh atribut yang disertakan cukup beragam dan saling terkait. Semantara realistasnya disebabkan oleh cara mengartikan yang subjektif antara seorang dengan yang lainnya dan sangat tergantung dengan perbandingan yang akan digunakan. Citra destinasi juga bukanlah sesuatau yang statis namun sangat dinamis seiring dengan terjadinya perubahan ruang, waktu dan tempat.

\section{Minat Wisatawan Berkunjung}

Minat merupakan kekuatan pendorong untuk minat dan keinginan seseorang yang menyebabkan seseorang menaruh perhatian pada suatu objek yang dia sukai yang berdampak pada peningkayan pasar. Minat merupakan suatu kesadaran seseorang terhadap suatu objek, seseorang, suatu soal atau juga situasi tertentu yang mengadung sangkut paut dengan dirinya atau dipandang ialah sebagai sesuatu yang sadar (Witherington, 2015). Adapun indikator dari Minat Wisatawan berkunjung yaitu objek wisata, fasilitas wisata, lingkungan wisata, kesadaran dan tujuan.

\section{Metodologi Penelitian}

\section{Kerangka Pemikiran}

Berdasarkan rumusan masalah dan landasan teori diatas, dapat disimpulkan bahwa Social Media Marketing (X1), Fasilitas Wisata (X2), dan Citra Destinasi Wisata (X3) berpengaruh terhadap Minat Wisatawan Berkunjung (Y). Maka dapat disusun suatu kerangka pemikiran dalam penelitian ini, seperti yang disajikan dalam gambar 2.1 berikut ini : 


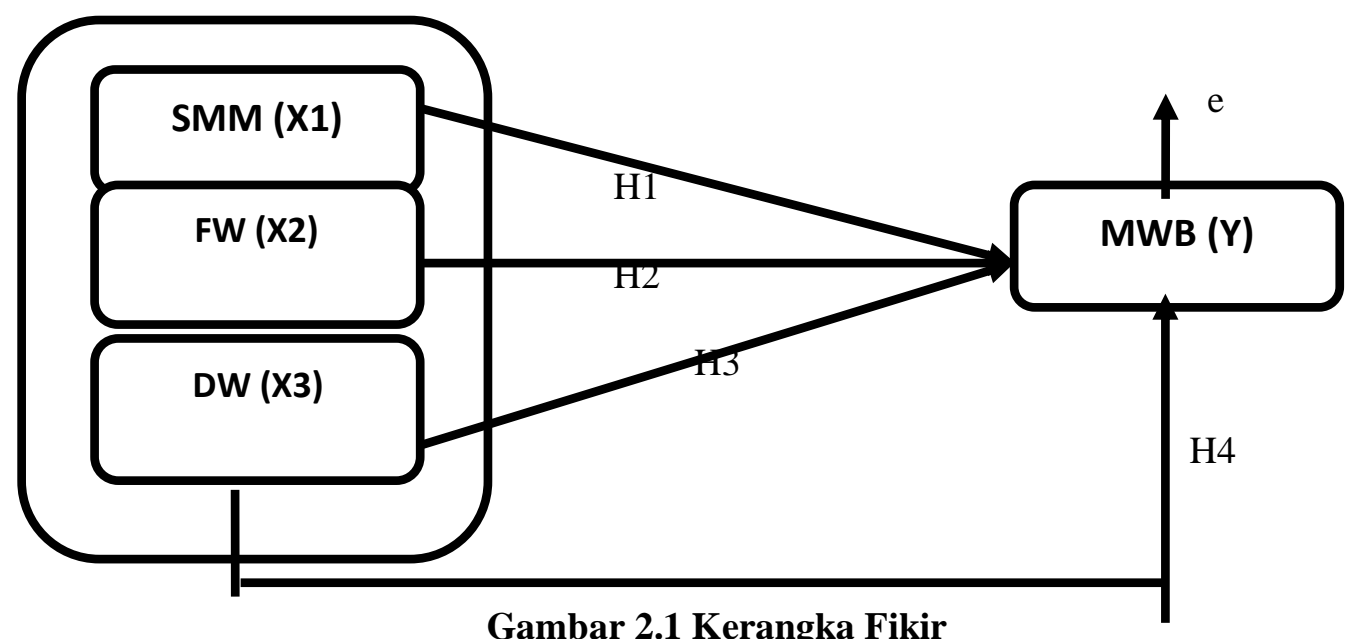

\section{Hipotesis}

Hipotesis diartikan sebagai dugaan sementara atau pendapat yang masih perlu dibuktikan kebenarannya. Adapun hipotesis pada penelitian ini adalah :

H1 : Social Media Marketing berpengaruh terhadap Minat Wisatawan Berkumpung pada Kawasan Mandeh

H2 : Fasilitas Wisata berpengaruh terhadap Minat Wisatawan Berkumpung pada Kawasan Mandeh

H3 : Citra Destinasi Wisata berpengaruh terhadap Minat Wisatawan Berkumpung pada Kawasan Mandeh

H4 : Social Media Marketing, Fasilitas Wisata dan Citra Destinasi Wisata terhadap Minat Wisatawan Berkumpung pada Kawasan Mandeh

\section{Objek Penelitian}

Penelitian ini dilakukan untuk mengetahui pengaruh social media marketing, fasilitas wisata, citra destinasi terhadap minat wisatawan berkunjung pada pulau Mandeh Kabupaten Pesisir Selatan di Sumatera Barat.

\section{Desain Penelitian}

Penelitian ini merupakan penelitian eksplanatori yaitu penelitian yang menguji hipotesis yang ada. Metode yang digunakan dalam penelitian ini adalah metode kuantitatif dengan menggunakan metode survei. Penelitian kuantitatif adalah penelitian yang menekankan pada penggunaan pertanyaan dengan standar formal dan sebelumnya telah ditetapkan pilihan jawaban dalam kuesioner yang dibagikan kepada responden.

\section{Popupasi dan Sampel}

\section{Populasi}

Menurut Sugiyono (2016) mengatakan populasi adalah wilayah generalisasi yang terdiri atas objek atau subjek yang mempunyai kualitas dan karateristik tertentu yang diterapkan oleh peneliti untuk dipelajari dan kemudian ditarik kesimpulannya. Jadi populasi bukan hanya orang, tetapi juga objek dan benda-benda alam lainnya. Populasi juga bukan sekedar jumlah yang ada pada obyek atau subyek yang dipelajari. tetapi meliputi karateristik atau sifat yang dimiliki oleh subyek atau obyek. Teknik pengumpulan data dengan menggunakan self administered survey yang mana masing-masing kuesioner diisi langsung oleh responden. Dalam penelitian ini digunakan 239 sampel yang disebarkan ke pengunjung yang ditemui di pulau Mandeh Kabupaten Pesisir, Sumatera Barat. 


\section{Hasil dan Pembahasan}

Hasil Uji Persamaan Regresi

Tabel 2 : Hasil Regresi Berganda

\begin{tabular}{|c|c|c|c|c|c|}
\hline \multirow[b]{3}{*}{ Model } & \multicolumn{3}{|c|}{ Coefficients $^{\mathrm{a}}$} & \multirow{3}{*}{$\mathbf{t}$} & \multirow{3}{*}{ ig. } \\
\hline & $\begin{array}{r}\text { Uns } \\
\text { C }\end{array}$ & $\begin{array}{l}\text { ardized } \\
\text { cients }\end{array}$ & $\begin{array}{c}\text { Standardized } \\
\text { Coefficients }\end{array}$ & & \\
\hline & B & Std. Error & Beta & & \\
\hline 1 (Constant) & 1,131 & ,982 & & 1,152 & 251 \\
\hline Media Sosial Marketing &, 154 & ,049 & , 106 & 3,155 & ,002 \\
\hline Fasilitas Wisata & ,567 & ,042 & ,665 & 13,431 & ,000 \\
\hline Citra Destinasi Wisata & 205 & ,047 & 207 & 4,360 & 000 \\
\hline
\end{tabular}

a. Dependent Variable: Minat Berkunjung

Berdasarkan tabel diatas maka dapat dilihat persamaan regresinya yaitu :

$$
\mathrm{Y}=1,131+0,154 \mathrm{X}_{1}+0,567 \mathrm{X}_{2}+0,205 \mathrm{X}_{3}+\mathrm{e}
$$

Dari persamaan regresi berganda di atas dapat disimpulkan bahwa :

a) Nilai konstanta sebesar positif sebesar 1,131; artinya jika Media Sosial Marketing $\left(\mathrm{X}_{1}\right)$, Fasilitas Wisata $\left(\mathrm{X}_{2}\right)$ dan Citra Destinasi Wisata $\left(\mathrm{X}_{3}\right)$, diabaikan (0), maka Minat Berkunjung Kembali (Y) nilainya adalah sebesar 1,131 satuan.

b) Koefisien regresi variabel Media Sosial Marketing positif sebesar 0,154; jika Media Sosial Marketing ditingkatkan satu (1) satuan dengan asumsi Fasilitas Wisata dan Citra Destinasi Wisata bernilai tetap (0) maka Minat Berkunjung Kembali akan mengalami peningkatan sebesar 0,154 satuan.

c) Koefisien regresi variabel Fasilitas Wisata positif sebesar 0,567; jika Fasilitas Wisata ditingkatkan satu (1) satuan dengan asumsi Media Sosial Marketing dan Citra Destinasi Wisata bernilai tetap (0) maka Minat Berkunjung Kembali akan mengalami peningkatan sebesar 0,567 satuan.

d) Koefisien regresi variabel Citra Destinasi Wisata positif sebesar 0,205; jika Citra Destinasi Wisata ditingkatkan satu (1) satuan dengan asumsi Media Sosial Marketingdan Fasilitas Wisata bernilai tetap (0) maka Minat Berkunjung Kembali akan mengalami peningkatan sebesar 0,205 satuan.

\section{Hipotesis}

Hasil Uji-t (Persial)

berikut ini :

Destinasi Wisata terhadap Minat Berkunjung Kembali maka dapat disajikan pada tabel

Tabel 3 Hasil Uji-t

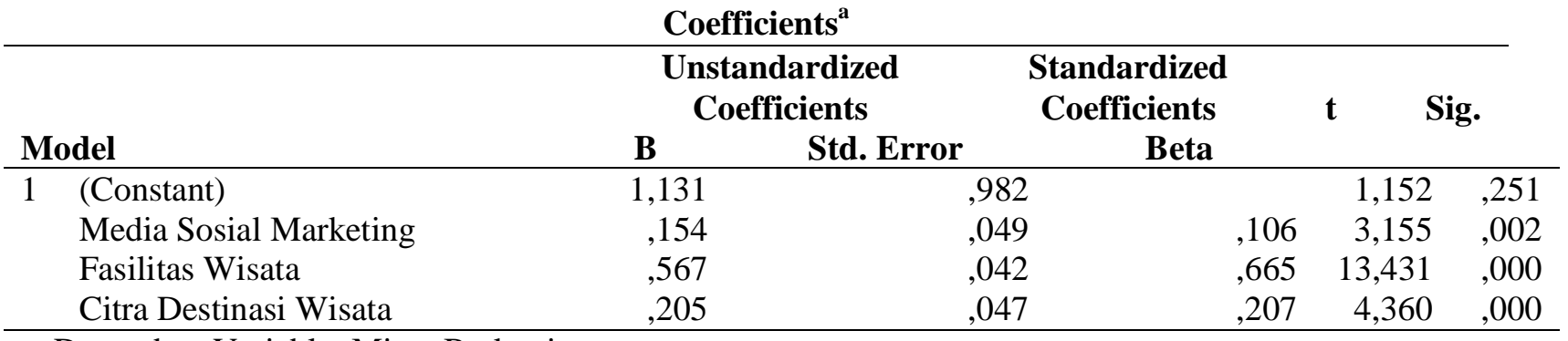

a. Dependent Variable: Minat Berkunjung

Dari hasil tabel diatas terdapat Pengaruh yang signifikan secara persial Media Sosial Marketing, Fasilitas Wisata dan Citra Destinasi Wisata terhadap Minat Berkunjung Kembali Wisatawan pada Kawasan Mandeh, Pesisir Selatan. Dimana ketahui tingkat siginifikan kecil dibandingkan alpha sebesar 0,05 atau 5\% pada variabel Media Sosial Marketing, Fasilitas Wisata dan Citra Destinasi Wisata. 


\section{Hasil Uji-F (Simultan) \\ Tabel 4 Hasil Uji-F}

ANOVA $^{\mathrm{a}}$

\begin{tabular}{|c|c|c|c|c|c|c|}
\hline \multicolumn{2}{|c|}{ Model } & \multirow{2}{*}{$\frac{\text { Sum of Squares }}{3093,860}$} & \multirow[t]{2}{*}{ df } & Mean Square & \multirow{2}{*}{$\frac{\mathbf{F}}{344,231}$} & \multirow{2}{*}{$\begin{array}{l}\text { Sig. } \\
, 000^{\mathrm{b}}\end{array}$} \\
\hline 1 & Regression & & & 1031,287 & & \\
\hline & Residual & 704,040 & 235 & 2,996 & & \\
\hline & Total & 3797,900 & 238 & & & \\
\hline
\end{tabular}

a. Dependent Variable: Minat Berkunjung Kembali

b. Predictors: (Constant), Citra Destinasi Wisata, Fasilitas Wisata, Media Sosial Marketing

Sumber : Data yang diolah 2020

Berdasarkan tabel diatas didapatkan sig yaitu $0,000<0,05$ maka penulis berkesimpulan Media Sosial Marketing, Fasilitas Wisata dan Citra Destinasi Wisata mempunyai pengaruh yang berarti atau signifikan dengan Minat Berkunjung Kembali.

\section{Hasil Koefisien Determinasi $\left(\mathbf{R}^{2}\right)$}

Koefisien determinasi $\left(\mathrm{R}^{2}\right)$ digunakan untuk mengetahui kontribusi variabel bebas dalam menjelaskan variabel terikat. Semakin besar nilai koefisien determinasi akan menunjukkan semakin besar pula pengaruh variabel bebas terhadap variabel terikat (Ghozali, 2016). Analisa koefisien determinasi dalam regresi linear berganda digunakan untuk mengetahui persentase sumbangan pengaruh variabel independen yang terdiri dari Media Sosial Marketing $\left(\mathrm{X}_{1}\right)$, Fasilitas Wisata $\left(\mathrm{X}_{2}\right)$ dan Citra Destinasi Wisata $\left(\mathrm{X}_{3}\right)$ secara simultan terhadap Minat Berkunjung Kembali (Y).

\section{Tabel 5 Hasil Uji Koefisien Determinasi}

Model Summary

\begin{tabular}{ccccc}
\hline Model & R & R Square & $\begin{array}{c}\text { Adjusted R } \\
\text { Square }\end{array}$ & $\begin{array}{c}\text { Std. Error of the } \\
\text { Estimate }\end{array}$ \\
\hline 1 &, $903^{\text {a }}$ &, 815 &, 812 & 1,731 \\
\hline
\end{tabular}

Sumber : SPSS 21.0 dan data primer yang diolah

Berdasarkan tabel di atas diperoleh angka Adjusted R Square sebesar 0,812 atau 81,2\%, hal ini menunjukkan bahwa persentase sumbangan variabel independen Media Sosial Marketing $\left(\mathrm{X}_{1}\right)$, Fasilitas Wisata $\left(\mathrm{X}_{2}\right)$ dan Citra Destinasi Wisata $\left(\mathrm{X}_{3}\right)$ terhadap variabel dependen Minat Berkunjung Kembali (Y) sebesar 0,812 atau 81,2\%. Sedangkan sisanya sebesar 18,8\% dipengaruhi oleh variabel lain di luar penelitian ini.

\section{Kesimpulan}

Dari Berdasarkan hasil penelitian yang telah dilakukan, maka penulis dapat mengimplikasikan hal-hal sebagai berikut:

\section{Pengaruh media sosial marketing terhadap minat berkunjung wisatawan}

Berdasarkan hasil analisis data penelitian ketahui nilai koefisien regresi media sosial marketing positif sebesar 0,154 dan tingkat siginifikan $(0,002<0,05)$, artinya secara parsial ada pengaruh yang signifikan antara media sosial marketing terhadap minat wisatawan berkunjung.

Sosial media memiliki peranan penting dalam menjalankan strategi digital marketing karena dapat meningkatkan brand awareness. Sosial media pun memegang arti yang sangat penting dan menjadi bagian gaya hidup sebagian besar masyarakat di seluruh Indonesia. Masyarakat Indonesia sudah bisa menggunakan sosial media dan dipastikan jumlahnya akan semakin bertambah seiring berkembangnya teknologi. Hasil pada penelitian ini menunjukan pengaruh yang positif dan signifikan antara sosial media marketing terhadap minat berkunjung kembali. Namun nilai koefisiennya lebih kecil dibandingkan variabel yang lain hal ini didapatkan karena wisatawan yang berkunjung mengenal wisata kawasan mandeh lebih banyak dari saudara, rekan kerja dan teman dibandingkan sosial media seperti instagram, facebook, twitter dan lainnya. Hal ini perlu menjadi perhatian bersama dalam 
mengelola pariwisata daerah untuk meningkatkan jaringan informasi media yang lebih luas sehingga dapat memperlihatkan perkembangan wisata. Sehingga wisatawan yang sudah berkunjung dan belum berkunjung ingin merasakan keindahan pariwisata kawasan mandeh.

Hasil penelitian ini juga didukung oleh penelitian yang dilakukan oleh Mavragani (2019) dengan judul Traveler segmentation through Social Media for intercultural marketing purposes: The case of Halkidiki. Dengan hasil penelitiannya dengan mensurvey pengguna di Instagram, Facebook, Twitter dan beberapa sosial media lainnya. Dengan hasil penelitiannya yang menunjukan adanya pengaruh yang besar sosial media marketing terhadap minat berkunjung.

\section{Pengaruh Fasilitas Wisata terhadap minat berkunjung wisatawan}

Berdasarkan hasil analisis data penelitian ketahui nilai koefisien regresi fasilitas wisata positif sebesar 0,567 dan tingkat siginifikan $(0,00<0,05)$, artinya secara parsial ada pengaruh yang signifikan antara fasilitas wisata terhadap minat wisatawan berkunjung.

fasilitas wisata adalah sarana dan prasarana pendukung yang selalu siap dimanfaatkan oleh para wisatawan dan pelayanan tersebut menawarkan hal - hal kebutuhan wisatawan seperti lokasi parkir, penginapan, sarana pemaianan dan lain sebagainya. Ketika fasilitas wisata dapat memberikan kepuasan maksimal kepada para pengunjung, akan menjadi dasar yang baik untuk mereka melakukan kunjungan kembali dimasa yang akan datang dan kesediaan mereka untuk menceritakan hal-hal positif kepada orang lain. Hal ini tentu menjadi alasan bagi pariwisata kawasan mandeh untuk tetap meningkatkan kualitas pariwisatanya, seperti pembangunan sarana jalan yang dapat dilalui oleh kendaraan, penginapan bagi pengunjung luar daerah, kendaraan umum dan segala macam yang dapat diakses oleh wisatawan.

Hasil penelitian ini menunjukan bahwa fasilitas pariwisata pada kawasan mandeh mempunyai nilai koefisien yang lebih besar dibandingkan variabel yang lain, sehingga semakin meningkatkan fasilitas wisata pada kawasan Mandeh maka akan semakin besar minat wisatawan untuk berkunjung. Hal ini didukung oleh penelitian yang dilakukan oleh Abdulhaji (2016) dengan judul Pengaruh Atraksi, Aksesibilitas, Dan Fasilitas Terhadap Citra Objek Wisata Danau Tolire Besar Di Kota Ternate. Hasil penelitian menunjukkan bahwa implementasi atraksi, aksessibilitas, fasilitas dan citra objek wisata Danau Tolire Besar dalam kategori baik, dan hasil uji hipotesis menunjukkan bahwa atraksi, aksessibilitas dan fasilitas dapat berpengaruh signifikan terhadap citra objek wisata Tolire Besar.

\section{Pengaruh Citra Destinasi Wisata terhadap minat berkunjung wisatawan}

Berdasarkan hasil analisis data penelitian ketahui nilai koefisien regresi citra destinasi wisata positif sebesar 0,205 dan tingkat siginifikan $(0,00<0,05)$, artinya secara parsial ada pengaruh yang signifikan antara citra destinasi wisata terhadap minat wisatawan berkunjung.

Alasan seseorang ingin berkunjung kembali ke objek wisata adalah bagaimana destinasi wisata yang akan mereka kunjungi. Citra destinasi didefinisiskan tidak hanya sebagai atribut destinasi tetapi juga kesan menyeluruh yang ditampilkan oleh destinasi. Multi dimensinya citra destinasi juga disebabkan oleh atribut yang disertakan cukup beragam dan saling terkait. Semantara realistasnya disebabkan oleh cara penafsirannya yang subjektif antara seorang dengan yang lainnya dan sangat tergantung dengan perbandingan yang akan digunakan. Citra destinasi juga bukanlah sesuatau yang statis namun sangat dinamis seiring dengan terjadinya perubahan ruang, waktu dan tempat. 


\section{DAFTAR PUSTAKA}

Abdulhaji, Sulfi; Yusuf, I. S. H. (2016). PENGARUH ATRAKSI, AKSESIBILITAS, DAN FASILITAS TERHADAP CITRA OBJEK WISATA DANAU TOLIRE BESAR DI KOTA TERNATE. Jurnal Penelitian Humano. https://doi.org/10.15713/ins.mmj.3

Basuki, A. T. dan, \& Prawoto, N. (2016). Analisis Regresi Dalam Penelitian Ekonomi \& Bisnis: Dilengkapi Aplikasi SPSS \& EVIEWS. In PT Rajagrafindo Persada.

Ghozali, imam. (2016). Aplikasi Analisis Multivariete Dengan Program IBM SPSS 23 (Edisi 8). In Universitas Diponegoro. https://doi.org/https://doi.org/10.3929/ethz-b-000238666

Jansen-Verbeke, M. (1986). Inner-city tourism: Resources, tourists and promoters. Annals of Tourism Research. https://doi.org/10.1016/0160-7383(86)90058-7

Mavragani, E. (2019). Traveler segmentation through Social Media for intercultural marketing purposes : The case of Halkidiki. Journal of Tourism, Heritage \& Services Marketing.

Rangkuti, F. (2013). Teknik Membedah Kasus Bisnis Analisis SWOT Cara Perhitungan Bobot, Rating, dan OCAI. In PT. Gramedia Pustaka Utama. Jakarta.

Riduwan, \& Sunarto. (2017). Pengantar Statistika untuk Penelitian: Pendidikan, Sosial, Komunikasi, Ekonomi dan Bisnis. In Bandung.

sugiyono. (2014). Metode penelitian. In Metode Penelitian.

Sugiyono, P. D. (2016). metode penelitian kuantitatif, kualitatif,dan R\&D. In Alfabeta, $c v$.

Witherington, $\quad$ B. $\quad$ (2015). $\quad$ Revelation. $\quad$ In Revation. https://doi.org/10.7591/cornell/9780801454134.003.0004 